\title{
Increased serum vaspin concentration in full-term neonates with early-onset infections
}

\author{
Dominika Wiśniewska-Ulfik', Jakub Behrendt ${ }^{1}$, Alicja Nawrat' ${ }^{1}$, Anna Szymańska', \\ Aneta Stachurska-Klimczak', Małgorzata Stojewska² \\ 'Department of Neonatal Intensive Care, School of Medicine with the Division of Dentistry in Zabrze, Medical University \\ of Silesia, Zabrze, Poland \\ ${ }^{2}$ Department of Paediatrics in Zabrze, School of Medicine with the Division of Dentistry in Zabrze, Medical University \\ of Silesia, Zabrze, Poland
}

\section{ABSTRACT}

Aim of the study: The evaluation of serum vaspin concentration (SVC) in full-term, appropriate for gestational age (AGA) neonates, according to their sex, gestational age, anthropometric parameters, type of delivery, birth asphyxia, and kind of infection.

Material and methods: In 183 full-term neonates, 102 infected and 81 healthy, 108 male and 75 female, 119 born vaginally and 64 by caesarean section, SVC was measured in serum of peripheral venous blood by ELISA test between the third and seventh day of life. The study was approved by the Ethics Committee of the Medical University of Silesia in Katowice. The neonates were divided into two groups: group I - 102 infected; and group II (control) - 81 healthy full-term neonates from physiological pregnancies. Early-onset infection involved sepsis (24 cases), bilateral pneumonia (38 cases), urinary tract infection (24 cases), purulent omphalitis, dermatitis, purulent meningitis, and osteomyelitis.

Results: In infected neonates the SVC ranged from 0.093 to $1.19 \mathrm{ng} / \mathrm{ml}$, and in the control group from 0.018 to $0.580 \mathrm{ng} / \mathrm{ml}$. It was stated that infected neonates have significantly $(p<0.002)$ higher SVC than healthy neonates. Septic neonates had the highest value, significantly higher than local infected neonates. We did not observe any differences between infected males and females, or between those born by caesarean section and those delivered vaginally. Healthy girls had significantly higher SVC than the healthy boys. No correlation was noted between SVC and anthropometric parameters in both healthy and infected neonates and between sex, birth asphyxia, and C-reactive protein value in infected babies.

Conclusions: Early-onset infections, especially sepsis, increase SVC in full-term, AGA neonates independently of their sex, birth asphyxia, and type of delivery.

\section{KEY WORDS:}

vaspin, early-onset infection, full-term neonate.

\section{INTRODUCTION}

Despite broad international efforts, neonatal infections, even in developed countries, remain the leading cause of mortality. In 2015, one million neonates died of infection globally. Neonatal sepsis accounts for about $15 \%$ of all infant deaths in the United States and 25\% of infant mortality worldwide $[1,2]$. Neonatal sepsis can be difficult to diagnose and is often fatal if not promptly treated with antibiotics. Maternal infections, and environmental

\section{ADDRESS FOR CORRESPONDENCE:}

Dominika Wiśniewska-Ulfik, Department of Neonatal Intensive Care, School of Medicine with the Division of Dentistry in Zabrze, 13-15 3 Maja St., 41-800 Zabrze, Poland, ORCID: 0000-0002-8099-1603,

e-mail: dominika.ulfik@gmail.com 
and infant factors influence the acquisition of bacterial and viral infections in the perinatal and neonatal period [3]. The clinical manifestations range from subclinical infection to severe signs of focal or systemic disease [4]. The lack of accurate diagnostic markers during the early neonatal period, immunological immaturity, and several sociodemographic disparities are the main causes of mortality [3,5-7]. The incidence of infections (in 30 neonatology units in United Kingdom) was 6.1/1000 live birth [8]. In southern Brazil among 745 deaths, 229 $(30.7 \%)$ had sepsis, with a neonatal mortality coefficient of 7.5/1000 live birth. Sepsis was involved in 2.3 deaths per 1000 live births [9].

In recent years some authors have emphasised the significance of endocrinological disorders in severely infected newborns - mainly the effect of early-onset infections on the increase of serum adiponectin, apelin, leptin, and resistin concentrations in eutrophic full-term neonates [10-13]. Moreover, congenital pneumonia, regardless of sex and birth asphyxia of neonates, increased serum vaspin concentration (SVC) [14].

Vaspin (visceral adipose tissue-derived serpin) consisted of 395 amino acids, encoded by the OL-64 gene on the long branch of chromosome 14 , is one of endocrine factors influencing foetal and neonatal development [1517]. The vaspin expression was detected in visceral and white subcutaneous adipose tissue, mucous membranes in the stomach, liver, pancreas, and cerebrospinal fluid $[18,19]$. This adipokine is a significant prognostic marker of major adverse cardiac events in patients with acute myocardial infarction [20]. Higher SVC was determined in obese children with metabolic syndrome and significantly correlated with high C-reactive protein (CRP) values [21]. Circulating vaspin strongly correlates with serum lipid profiles in humans, mainly with triacylglycerol, apolipoprotein A1, and low-density lipoprotein cholesterol [22]. Some authors emphasise sexual dimorphism of SVC in adults and children. They show that sex is an independent predictor of circulating vaspin in diabetic, obese, and nondiabetic patients, SVC increases with sexual maturation in girls, vaspin secretion is conditioned by nutrition status, and there is significantly higher SVC in female teenagers with anorexia nervosa than in healthy girls and lower in girls with Turner syndrome [23-25]. SVC in children with chronic kidney disease is significantly lower than in healthy children [26]. This hormone may be a potential novel biomarker for the prediction and early diagnosis of gestational diabetes [27]. A negative association between glucose and cord blood vaspin was found, as well as the predictive nature of glucose levels on vaspin levels, suggesting that vaspin can be used as a predictor of alterations in the high insulin-glucose metabolism since birth [28]. Cord blood vaspin level is significantly higher in small for gestational age (SGA) neonates than in appropriate for gestational age (AGA) and large for gestational age (LGA) infants, and it may be one of the factors of an increased risk of adult metabolic diseases [15]. SVC is higher in LGA newborns than in AGA ones and may suggest a defensive mechanism against insulin/ glucose dysregulation [29]. The effect of early-onset infections on SVC is not well known. SVC is significantly higher in septic adults than in critically ill patients receiving intensive care after trauma or major surgery [30]. Higher SVC than in healthy subjects was stated only in pneumonic full-term neonates [14]. The aim of our study was to evaluate SVC in severely infected neonates, considering their sex, Apgar score, type of delivery, birth weight and length, and head and chest circumferences.

\section{MATERIAL AND METHODS}

The study population consisted of 183 full-term, AGA, neonates aged from the third to seventh day of life, including 75 girls and 108 boys, 119 delivered vaginally and 64 by caesarean section. The study was approved by the Ethics Committee of the Silesian University of Medicine in Katowice. All parents or legal guardians of the neonates gave their informed consent to participate. Infected neonates were treated in the NICU in the University Hospital in Zabrze, within a timespan of two years (2013-15). Healthy neonates were delivered during the same time in the Obstetric Department in Gliwice, Poland. SGA and LGA neonates, preterm babies delivered by obese mothers, mothers with diabetes mellitus or with other endocrine disorders, hypertension, or myocardial ischaemic disease, and neonates with multiply defects and chromosome aberration were excluded from the study.

The neonates were divided into two groups: group I (tested) - 102 infected full-term neonates; group II (control) - 81 healthy full-term neonates from physiological pregnancies. Clinical data of both groups are shown in Table 1.

Early-onset infections ( $<3$ days of age) involved: sepsis (24 cases) - 17 due to Gram-positive bacteria (Staphylococcus aureus - eight cases, Staphylococcus epidermidis $M R$ - six cases, and Streptococcus agalactiae - three cases) and seven due to Gram-negative bacteria (E. coli - four cases, Klebsiella pneumoniae - three cases), bilateral pneumonia (38 neonates), urinary tract infection (24 cases, mainly due to E. coli, Klebsiella pneumoni$a e$ ), purulent omphalitis, dermatitis and conjunctivitis (14 cases) caused by Staphylococcus species (10 cases) and Streptococcus B (four cases), purulent meningitis (one case), and osteomyelitis (one case).

All infected neonates with respiratory and/or cardiovascular disorders were treated with broad-spectrum antibiotics (gentamycin and $\beta$-lactam antibiotic) from the first day of life. Monotherapy (ampicillin) in purulent dermatitis, conjunctivitis, and omphalitis was applied. In five cases of staphylococcal sepsis, it was necessary to administer vancomycin. In the case of five neonates mechanical ventilation was used, in 15 - nCPAP, and in 22 - total parenteral nutrition. Serum glucose concentration 
TABLE 1. Clinical characteristics of study and control groups of neonates

\begin{tabular}{|c|c|c|c|c|c|c|c|c|}
\hline \multirow{2}{*}{$\begin{array}{l}\text { Group } \\
\text { of newborns }\end{array}$} & \multirow[t]{2}{*}{ Gender } & \multirow[t]{2}{*}{ Parameters } & \multirow{2}{*}{$\begin{array}{l}\text { Body weight } \\
\text { (g) }\end{array}$} & \multirow{2}{*}{$\begin{array}{l}\text { Length } \\
(\mathrm{cm})\end{array}$} & Head & Chest & \multicolumn{2}{|c|}{ Apgar score } \\
\hline & & & & & \multicolumn{2}{|c|}{ Circumference (cm) } & $<7$ & $>7$ \\
\hline \multirow{3}{*}{$\begin{array}{l}\text { Study } \\
(n=102)\end{array}$} & \multirow{3}{*}{$\begin{array}{c}m=71 \\
f=31\end{array}$} & $25-75 \%$ & 680.0 & 4.0 & 2.0 & 3.0 & \multirow[t]{3}{*}{15} & \multirow[t]{3}{*}{87} \\
\hline & & Median & 3310.0 & 54.0 & 33.5 & 33.0 & & \\
\hline & & Min-max & $2400.0-4280.0$ & $49.0-61.0$ & $30.0-38.0$ & $27.0-39.0$ & & \\
\hline \multirow{3}{*}{$\begin{array}{l}\text { Control } \\
(n=81)\end{array}$} & \multirow{3}{*}{$\begin{array}{c}m=37 \\
f=41\end{array}$} & $25-75 \%$ & 500.0 & 3.0 & 2.0 & 3.0 & \multirow[t]{3}{*}{0} & \multirow[t]{3}{*}{81} \\
\hline & & Median & 3340.0 & 55.0 & 33.0 & 33.0 & & \\
\hline & & Min-max & $2540.0-4290.0$ & $49.0-59.0$ & $31.0-36.0$ & $29.0-36.0$ & & \\
\hline
\end{tabular}

in both groups of neonates ranged from 2.8 to $5 \mathrm{mmol} / \mathrm{l}$. One recorded death was due to a fulminant Gram-negative sepsis shock due to Klebsiella agalactiae, complicated by disseminated intravascular coagulation syndrome and necrotising enterocolitis.

\section{METHODS OF CLINICAL STUDY}

Clinical data of all examined neonates were collected on case records. The foetal maturity was assessed based on pregnancy duration according to the Naegele formula, verified with ultrasound assessment, and after birth, in the first day of life, it was confirmed by a neonatologist using the new Ballard score [31].

Anthropometric measurements were performed immediately after birth and included birth weight and length, as well as head and chest circumferences.

Diagnosis of all early-onset neonatal infections was according to neonatal standards [32].

Birth asphyxia was diagnosed in the study group according to low Apgar score ( $<6$ points) in the first minute of life and $\mathrm{pH}$ of venous cord blood $<7.10$ in the first hour of life and serum lactate concentration $>2.5 \mathrm{mmol} / \mathrm{l}$.

\section{DETERMINATION OF SERUM VASPIN CONCENTRATION}

SVC was measured in serum of the peripheral vein blood by a commercially available ELISA test kit (Bio Vendor Research and Diagnostic Products, Brno, Czech Republic). Blood samples were collected from the third to the seventh day of life between 8.00 and 9.00 a.m., centrifuged, stored at $-70^{\circ} \mathrm{C}$, and measured by the same laboratory technician in the Biochemical Laboratory of University Hospital No. 1 in Zabrze. The test results were reported in $\mathrm{ng} / \mathrm{ml}$. None of the study's neonates received blood or haematogenous preparation beforehand.

\section{STATISTICAL ANALYSIS}

The results were statistically analysed with Statistica 11.0 software. Normality of the data was tested using the Kolmogorov-Smirnov test. Comparisons between groups were performed by the $U$ Mann-Whitney test. The Spear- man linear correlation coefficient test was used for the evaluation of correlation between the SVC and Apgar score, gestational age, and neonatal anthropometric parameters; $p$-values less than 0.05 were considered significant.

\section{RESULTS}

In infected newborns SVC ranged from 0.093 to $1.190 \mathrm{ng} / \mathrm{ml}$ and in the control group from 0.018 to 0.580 $\mathrm{ng} / \mathrm{ml}$. Infected neonates had significantly $(p<0.002)$ higher SVC (median and quartile $0.324 / 0.380$, range $0.093-1.190 \mathrm{ng} / \mathrm{ml})$ than healthy ones $(0.253 / 0.165$, range $0.018-0.580 \mathrm{ng} / \mathrm{ml}$ ) (Fig. 1). Septic neonates had the highest value $(0.405 / 0.165$, range $0.165-$ $1.125 \mathrm{ng} / \mathrm{ml})$, significantly $(p<0.03)$ higher than local infected neonates (respectively, 0.294/0.84, range 0.093-1.190 $\mathrm{ng} / \mathrm{ml}$ ). We did not observe significant differences $(p>0.05)$ between SVC in infected male (0.303/0.307, range 0.93-1.19) and female (0.328/0.303, range $0.123-1.160)$ neonates. Healthy full-term female neonates $(0.291 / 0.152$, range $0.018-0.475 \mathrm{ng} / \mathrm{ml})$ had significantly higher $(p<0.05)$ SVC than did the healthy male neonates $(0.220 / 0.126$, range $0.096-$ $0.580 \mathrm{ng} / \mathrm{ml}$ ) (Fig. 2). Significant negative linear correla-

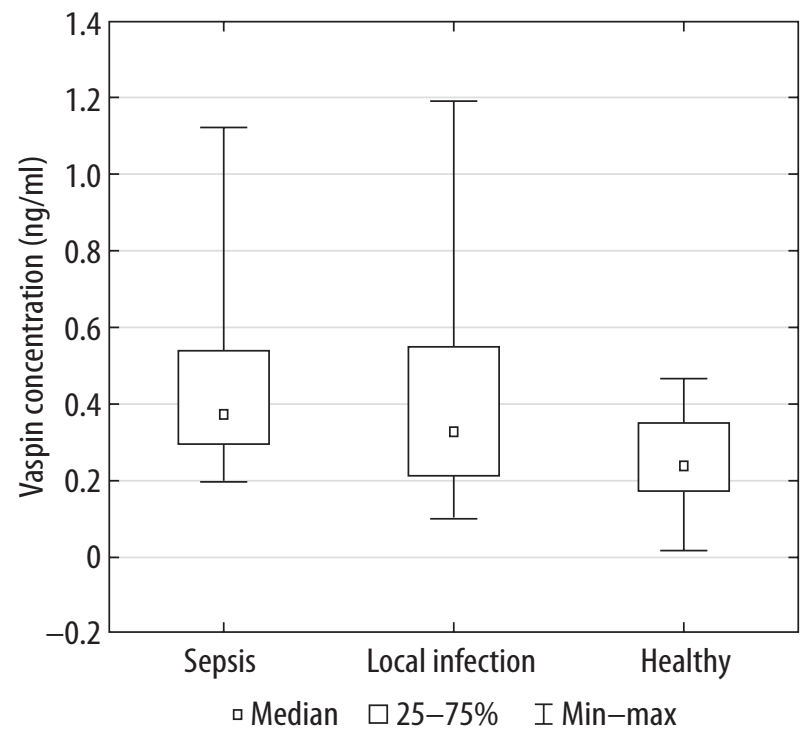

FIGURE 1. Comparison of serum vaspin concentration between septic, local infected and healthy full-term neonates 


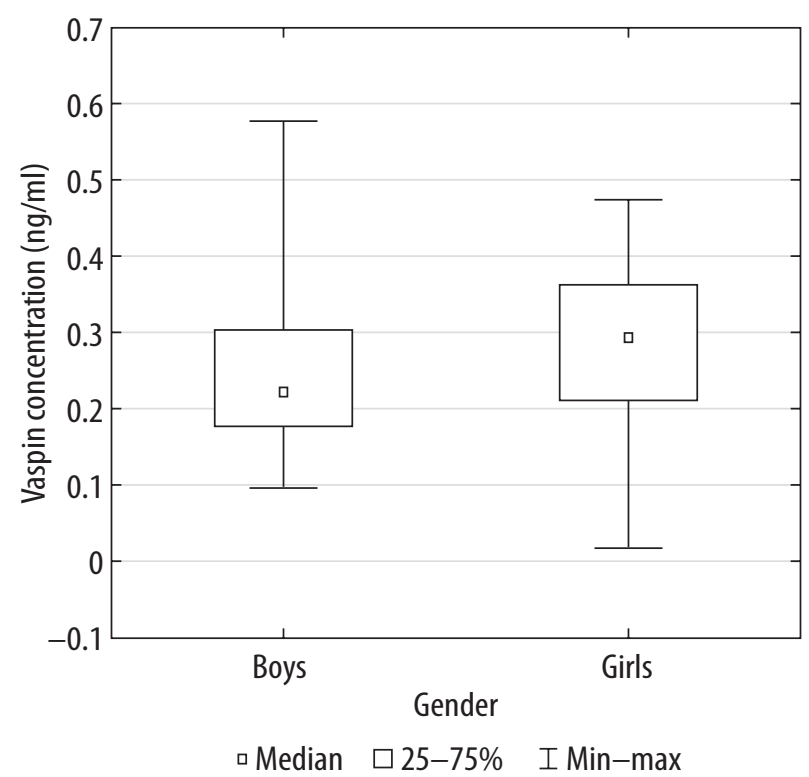

FIGURE 2. Comparison of serum vaspin concentration between healthy neonate males and females

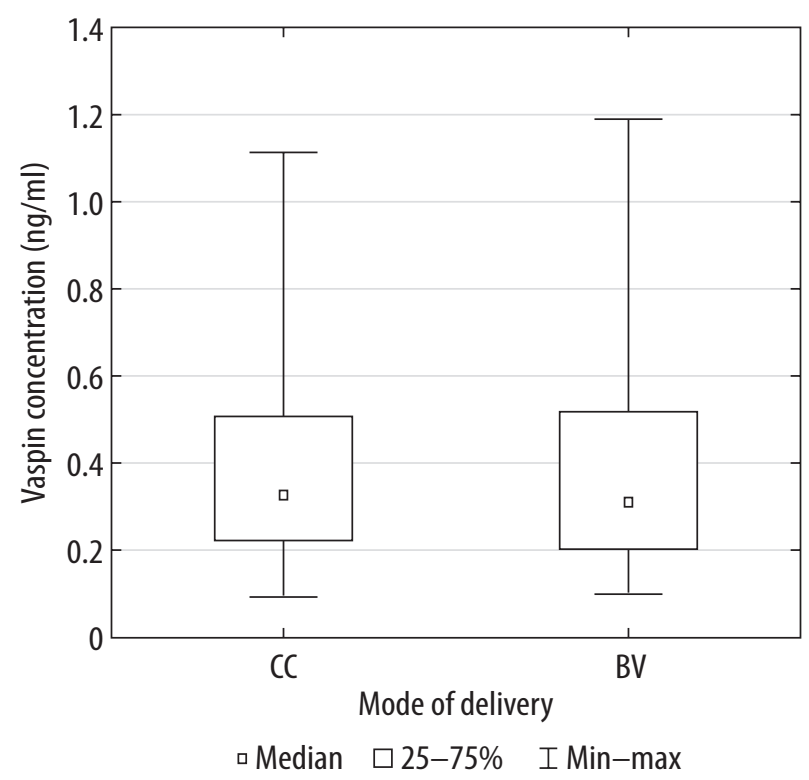

FIGURE 4. Comparison of serum vaspin concentration between infected neonates according to mode of delivery (caesarean section $-(C$, born vaginally $-B V)$

tion between SVC $(r=-0.24, p=0.015)$ and gestational age of infected neonates was noted (Fig. 3). We did not observe any significant differences between SVC in neonates born by caesarean section and those born vaginally in both groups (Figs. 4 and 5). We also did not observe any correlation between Apgar score in the first minute of life and SVC in the infected group (Fig. 6) or between SVC and birth asphyxia (Fig. 7).

SVC did not correlate with gestational age of healthy neonates $(r=-0.028, p=0.801)$ and with birth weight in both groups $(r=0.03, p=0.767 ; r=0.154, p=0.171)$. In healthy and infected neonates no correlation between SVC and body length $(r=-0.121, p=0.226$;

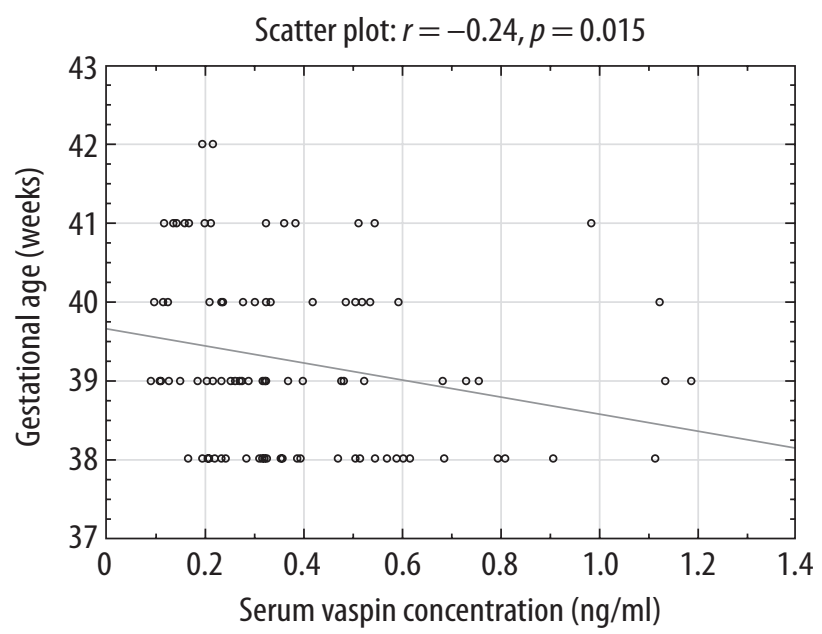

FIGURE 3. Comparison of serum vaspin concentration and gestational age of infected full-term neonates

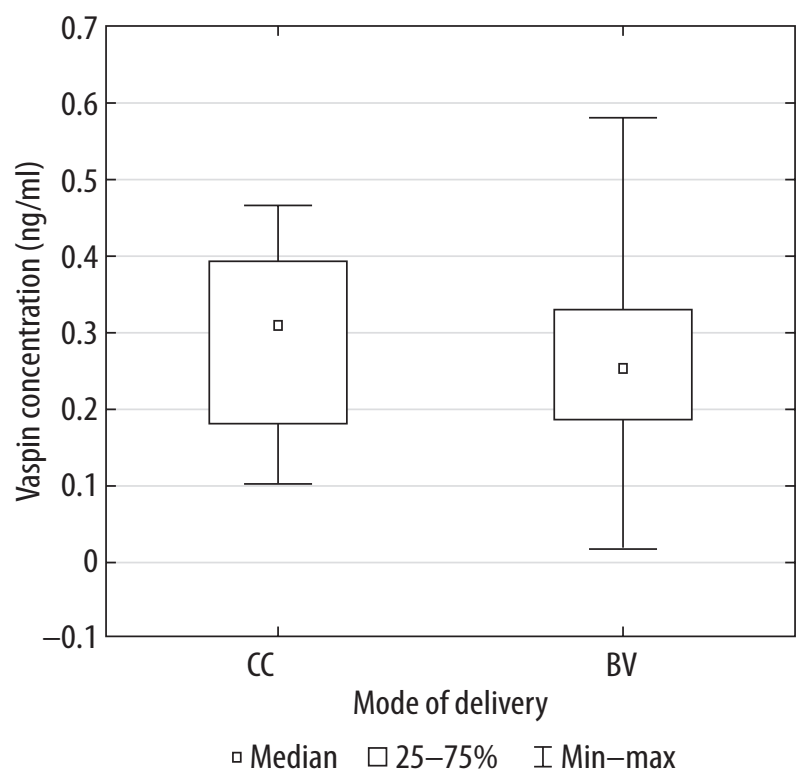

FIGURE 5. Comparison of serum vaspin concentration between healthy neonates according to mode of delivery (caesarean section - CC, born vaginally $-B V$ )

$r=-0.191, p=0.087$, head $(r=-0.102, p=0.310 ; r=-0.013$, $p=0.950)$ and chest $(r=0.069, p=0.491 ; r=0.066$, $p=0.559)$ circumferences was found. In infected neonates any correlation between SVC and CRP $(r=0.084$, $p=0.403)$ and platelet count $(r=0.081, p=0.43)$ was stated.

\section{DISCUSSION}

The results from the present study showed significantly increased SVC in full-term infected neonates compared to healthy ones. This seems to suggest that early-onset infections, especially bacterial sepsis, stimulate vaspin secretion. This fact could have clinical significance, representing a defensive neonatal mechanism against severe early-onset infections, and it may be a symptom of neonatal adaptation to some metabolic disorders, for example metabolic acido- 


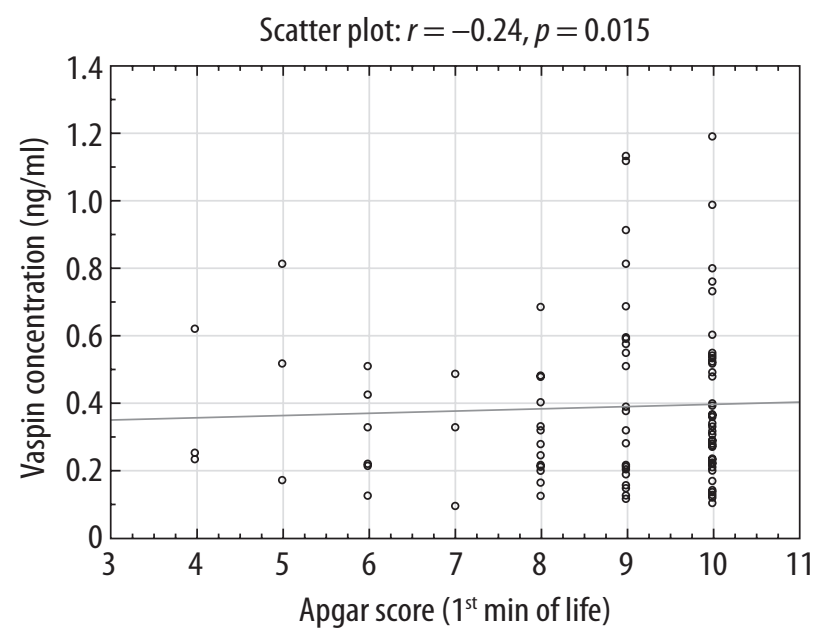

FIGURE 6. Correlation between serum vaspin concentration and Apgar score ( $11^{\text {st }} \mathrm{min}$ of life) in infected full-term neonates

sis connected with infection. Moreover, it may reflect the amount of developing adipose tissue in the early stage of inflammation due to infection, because we noted negative correlation between SVC and gestational age of infected neonates. Increase of SVC in infected neonates despite the lack of correlation with the CRP concentration and with thrombocytopenia may be useful in the diagnosis of infections. The study was limited by the low numbers of early-onset infected neonates, but in the future, assessment of SVC may be a new useful biomarker of these infections. Similarly to our study, in the first examination in adult patients with sepsis increased plasma vaspin concentration was demonstrated [30]. The authors noted a weak positive correlation between vaspin and CRP concentration [30]. Moreover, such stated other authors, this adipokine significantly correlated with high CRP values in obese children with metabolic syndrome, in whom higher vaspin concentrations were noted, than in children without this pathology [21]. In healthy adults vaspin is characterised by pulsatile secretion, and its concentration is approximately twice as high among women than in men $[17,33]$. We made a similar observation in our study. Healthy female neonates had significantly higher SVC than healthy male neonates. We confirm the hypothesis that neonatal anthropometric parameters (birth weight, length, head and chest circumferences) and type of delivery are not related to the SVC, but our study was performed only in full-term AGA neonates. Therefore, we believe that further clinical trials, both in full-term and preterm neonates, providing more information about the role of vaspin in development and metabolism regulation in infected neonates, are necessary. The role of the connection between vaspin and inflammation caused by early- and late-onset neonatal infections also needs to be evaluated further.

\section{CONCLUSIONS}

Early-onset infections, especially bacterial sepsis, have a significant influence on the increase of serum vaspin

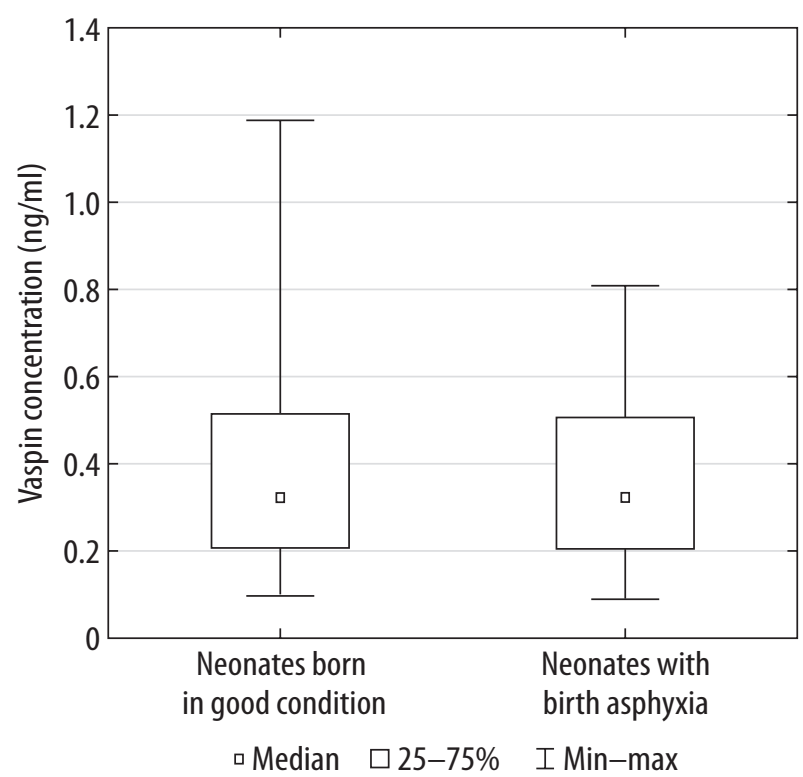

FIGURE 7. Comparison of serum vaspin concentration between infected neonates born in good condition and with birth asphyxia

concentration in full-term AGA neonates independently of their sex, birth asphyxia, and type of delivery.

In healthy and infected full-term neonates any significant correlations between vaspin concentrations and birth weight, body length, and chest and head circumferences were noted.

\section{DISCLOSURE}

The authors declare no conflict of interest.

\section{REFERENCES}

1. Liu L, Oza S, Hogan D, et al. Global, regional and national causes of child mortality in 2000-13 with projections to inform post 2015 priorities: an updated systematic analysis. Lancet 2015; 385: 430-440.

2. Simonsen KA, Anderson-Berry Al, Delair SF, Davies HD. Earlyonset neonatal sepsis. Clin Microbiol Rev 2014; 27: 21-47.

3. Khan AM, Morris SK, Bhutta ZA. Neonatal and perinatal infections. Pediatr Clin North Am 2017; 64: 7985-798.

4. Shane AL, Sanches PJ, Stoll BJ. Neonatal sepsis. Lancet 2017; 390: 1770-1780.

5. Kan B, Razzaghian HR, Lavoie PM. An immunological perspective on neonatal sepsis. Trends Mol Med 2016; 22: 290-302.

6. Iroh Tam PY, Bendel CM. Diagnostics for neonatal sepsis: current approaches and future directions. Pediatr Res 2017; 82: 574-583.

7. Bohanon FJ, Nunez Lopez O, Adhikari D, et al. Race, income and insurance status affect neonatal sepsis mortality and healthcare resource utilization. Pediatr Infect Dis J 2018; 37: 178-184.

8. Cailes B, Kortsalioudaki C, Buttery J, et al. Epidemiology of UK neonatal infections: the neonIN infection surveillance network. Arch Dis Child Fetal Neonatal Ed 2018; 103: F547-F553.

9. Alves JB, Gabani FL, Ferrari RAP, et al. Neonatal sepsis: mortality in municipality in southern Brazil, 2000-2013. Rev Paul Pediatr 2018; 36: 132-140.

10. Wiśniewska-Ulfik D, Godula-Stuglik U, Szymańska A, et al. Wpływ wczesnych zakażeń na stężenie adiponektyny i leptyny w surowicy noworodków donoszonych. Pediatr Pol 2017; 92: 242-251. 
11. Gad GI, Ismail RI, El-Masry SA, et al. Serum apelin in early-onset neonatal sepsis: it is diagnostic. J Neonatal Perinatal Med 2014; 7: 207-212.

12. Sadownik B, Lukas W, Behrendt J, et al. An analysis of factors determining serum leptin concentrations in healthy and infected newborns. Neuroendocrinol Lett 2010; 31: 221-228.

13. Stojewska M, Wnęko-Masłoń B, Nawrat A, et al. Stężenie rezystyny w surowicy noworodków donoszonych z zakażeniami wewnątrzmacicznymi. Pediatr Pol 2016; 91: 325-331.

14. Wiśniewska-Ulfik D, Godula-Stuglik U, Wąsek-Buko M, et al. Zmiany stężeń waspiny i leptyny w surowicy noworodków donoszonych z wrodzonym zapaleniem płuc. Pediatr Pol 2017; 92: 252-259.

15. Akcay A, Akar M, Demirel G, et al. Umbilical cord and fifthday serum vaspin concentrations in small-, appropriate- and large-for-gestational age neonates. J Pediatr Endocrinol Metab 2013; 26: 635-638.

16. Briana DD, Boutsikou M, Baka S, et al. Omentin-1 and vaspin are present in the fetus and neonate, and perinatal concentrations are similar in normal and growth-restricted pregnancies. Metabolism 2011; 60: 486-490.

17. Hida K, Wada J, Eguchi J, et al. Visceral adipose tissue-derived serine protease inhibitor. A unique insulin-sensitizing adipocytokine in obesity. Proc Natl Acad Sci USA 2005; 102: 10610-10615.

18. Li Q, Chen R, Moriya J, Yamakawa J, et al. A novel adipokine, visceral adipose tissue-derived serine protease inhibitor (vaspin and obesity). J Int Med Res 2008; 36: 625-629.

19. Li K, Li L, Yang M, et al. Short-term continuous subcutaneous insulin infusion decreases the plasma vaspin levels in patients with type 2 diabetes mellitus concomitant with improvement in insulin sensitivity. Eur J Endocrinol 2011; 164: 905-910.

20. Zhou X, Chen Y, Yao Y, et al. Serum vaspin as a predictor of adverse cardiac events in acute myocardial infarction. J Am Heart Assoc 2019; 22: e010934.

21. Buyukinan M, Atar M, Can U, et al. The association between serum vaspin and omentin-1 levels in obese children with metabolic syndrome. Metab Syndr Relat Disord 2018; 16: 76-81.

22. Breifeld J, Wiele N, Gutsmann B, et al. Circulating adipokine vaspin is associated with serum lipid profiles in humans Lipids 2019; 54: 203-210.

23. Körner A, Neef M, Friebe D, et al. Vaspin is related to gender, puberty and deteriorating insulin sensitivity in children. Int J Obes (Lond) 2011; 35: 578-586.

24. Grzelak T, Tyszkiewicz-Nwafor M, Dutkiewicz A, et al. Neuropeptide $\mathrm{B}$ and vaspin as new biomarkers in anorexia nervosa. BioMed Res Int 2018; 2018: 9727509.

25. Zhang Y, Chen RM, Lin XQ, et al. The correlation between serum adipokines levels and metabolic indicators in girls with Turner syndrome. Cytokine 2019; 113: 139-143.

26. Szczepańska M, Machura E, Adamczyk P, et al. Evaluation of adipocytokines in children with chronic kidney disease. Endokrynol Pol 2015; 66: 100-107.

27. Mierzyński R, Poniedziałek-Czajkowska E, Dłuski D, et al. Nesfatin- 1 and vaspin as potential novel biomarkers for the prediction and early diagnosis of gestational diabetes mellitus. Int J Mol Sci 2019; 20: E159.

28. Hernández-Rodríguez CE, Estrada Zúñiga CM, De la O-Cavazos $\mathrm{ME}$, et al. Vaspin, a compensatory mechanism against high glucose levels since birth. J Clin Res Pediatr Endocrinol 2019; 11: 125-131.

29. Kafalidis G, Boutsikou T, Briana DD, et al. Adipokines vaspin and omentin-1 are up-regulated in large for gestational age infants at term. Cytokine 2013; 62: 70-74.

30. Motal MC, Klaus DA, Lebherz-Eichinger D, et al. Increased plasma vaspin concentration in patient with sepsis: an exploratory examination. Biochem Med (Zagreb) 2015; 25: 90-96.
31. Ballard JL, Koury JC, Wedig K, et al. New Ballard score, expanded to include extremely premature infants. J Pediatr 1991; 119: 417423.

32. Lauterbach R. ABC zakażeń u noworodków. In: Neonatologia ( $2^{\text {nd }}$ ed.), Szczapa J (ed.). Warszawa 2015: 295-306.

33. Koiou E, Kalaitzakis E, Tziomalos K, et al. Vaspin: a novel adipokine, member of the family of serine protease inhibitors. Aristole University Medical Journal 2011; 38: 7-18. 